\title{
A new witness of the third recension of ps.-Methodius' Revelationes: Winithar's manuscript St Gallen, Stiftsbibliothek, MS 238 and the role of Rome in human history
}

\author{
CinZIA GRIFONI
}

Winithar, monk and decanus at Saint-Gall in the second half of the eighth century, is known to modern scholarship as the writer of one charter and of several manuscripts. This article focuses on Winithar's autograph St Gallen 238 , arguing that its various texts were in part collected and copied, and in part perhaps composed by Winithar himself, in light of a specific editorial plan. In this plan, the text entitled De gentibus, a new witness of the Revelationes by ps.-Methodius in its so-called third recension, confers on the Romans of Rome the leading role among western peoples until Judgement Day.

'Winitharius ist der erste produktive, kreative Schriftsteller, der erste uns bekannte Autor im jungen Kloster St. Gallen' ('Winithar is the first productive and creative writer, the first author we know in the young monastery of Saint-Gall'). ${ }^{\mathrm{I}}$ With these words Peter Ochsenbein, former director of the Stiftsbibliothek in St Gallen, described the activity of the monk Winithar, the first scribe and author from Saint-Gall to be known by name, whose floruit must be set in the second half of the eighth century. Winithar came to Saint-Gall around 760 , probably following the newly appointed abbot Johannes, and held later the eminent position of

* The research leading to these results has received funding from the European Research Council under the European Union's Seventh Framework Programme (FP7/2007-20I3) / ERC grant agreement No. 26959I. I am very grateful to Rosamond McKitterick, John Buczak, Clemens Gantner, Ingrid Hartl and Bernhard Zeller for their precious suggestions and comments.

P. Ochsenbein, 'Sonderling im Galluskloster: Winitharius - der erste Schriftsteller des Klosters St. Gallen', in E. Tremp (ed.), Cultura Sangallensis. Gesammelte Aufsätze (St Gallen, 200o), pp. I48-53, at p. I5I. 
decanus of the monastery. ${ }^{2} \mathrm{He}$ is known to modern scholars first of all as the writer and subscriber of a single charter from the year 76I, which is still preserved in the archives at St Gallen in its original version. ${ }^{3}$ However, the peculiar traits of his hand ${ }^{4}$ have been identified in several Saint-Gall manuscripts or parts of them dating to the same period.'

Among these manuscripts one plays a particular role: it is St Gallen, Stiftsbibliothek, MS 238, on which the present contribution shall focus. ${ }^{6}$ This codex is acknowledged in its entirety as Winithar's autograph, not only because of the paleographical affinity with the original charter mentioned above, but also by reason of four sentences placed in different parts of the volume in which the scribe calls himself by name, claiming in the first instance to be the author of two specific texts of the collection. The first two self-references precede and follow the question and answer introduction to the Pentateuch, whose composition Winithar ascribes to himself:

Incipiunt dicta Winitharii presbiteri de quinque libris Moysi (added in ornamental capitals on the margin of p. 178$)^{7}$

Explicit proplema Winitharii presbiteri, qui hunc librum scripsit et conplevit a fine usque in finem. Omnis enim qui legerit, oret pro eo qui scripsit, si Deum habeat propiciatorem. Amen Alleluia (on p. I8I). ${ }^{8}$

2 A survey of the achievements of modern scholarship as well as new insights into Winithar's biography, cultural activity, palaeographical and linguistic features can now be found in W. Berschin and B. Zeller, 'Winithar in Sankt Gallen (um 760-?) und der Versus Winitharii', in M. Diesenberger, Y. Hen and M. Pollheimer (eds), Sermo doctorum: Compilers, Preachers, and their Audiences in the Early Medieval West (Turnhout, 2013), pp. 153-86.

3 See charter no. 34 in H. Wartmann (ed.), Urkundenbuch der Abtei Sanct Gallen, I: Jahr 700-840 (Zurich, I863), pp. 33-4 = Chartae Latinae Antiquiores I, ed. A. Bruckner (Olten, I954), no. 57, pp. 60-I.

4 For a palaeographical description of Winithar's hand, see for instance K. Löffler, 'Die Sankt Galler Schreibschule in der 2. Hälfte des 8. Jahrhunderts', Paleographia Latina 6 (1929), pp. 5-66, at pp. 60-6, and Berschin and Zeller, 'Winithar in Sankt Gallen', pp. 156-7.

s St Gallen, MSS 70, 238 and 907 are usually acknowledged as Winithar's autographs in their entirety, whereas only parts of St Gallen, MSS 2, II, I09, I399a and 225 are ascribed to him by the majority of scholars. Also the codex Vienna, Österreichische Nationalbibliothek, MS Lat. 743 is considered by some scholars to be strictly related to Winithar's activity.

6 This and all of Winithar's other manuscripts, as well as their standard description by Gustav Scherrer and Anton Euw are available online at: <http://www.e-codices.unifr.ch/de/list/csg/ Shelfmark>.

7 'Here begin the explanations by Winithar the priest about the five Books of Moses.'

8 'Here ends the proplema [see hereinafter for the meaning of this term] by Winithar the priest, who wrote and accomplished this book from end to end. May everyone who reads it pray for the writer, so that God may be propitious to him. Amen. Hallelujah.' 
The third self-reference occurs on p. 305, at the end of the prologue to the genealogy of Christ, where Winithar at first writes only explicet prolocus, adding then with a different ink:

quem Winitharius presbiter ex sua scripsit memoria. ${ }^{9}$

The colophon at the end of the manuscript, on p. 493, includes the last self-reference:

Deo et Christo gloria quia explicet liber, quem Winitharius peccator et inmerito ordinatus presbiter scripsit, ex suo proprio labore Deo auxiliante perfecit, et non est hic nec unus folius, quem ille de suo labore non adquississet aut conparando aut mendicando, et non est in hoc libro unus apex aut iota una, quem manus eius non pincxisset. ${ }^{10}$

With this sentence Winithar affirms that he, sinner and undeservedly ordained priest, ${ }^{\mathrm{II}}$ is the one who painstakingly gathered every single leaf of the book and wrote every single letter thereof, even the smallest one.

Now, if we believe these four sentences and accept that the manuscript St Gallen 238 is the product not only of the scribal but also of the cultural activity of Winithar, every text in it and the book as a whole become important pieces of evidence which help to reconstruct both the interests of the compiler, and the aim he had in mind before collecting specific sources or even composing new texts. Therefore I shall concentrate on the structure of the manuscript (see Table I), which I consider to be a unity in its conception, paying particular attention to those texts which reveal an interesting view of the role of Rome in human history.

\section{St Gallen, Stiftsbibliothek, MS 238: a description}

The manuscript St Gallen 238 features in its initial part a very long and rich glossary in the form of a mainly $\mathrm{AB}$-ordered list of words, which are

9 'Here ends the prologue which Winithar wrote according to his memory.'

10 'Be glory to God and Christ for here ends the book which Winithar, a sinner and an undeservedly ordained priest, wrote and accomplished through both his work and God's help. There is no single leaf in it, which he did not procure through his work, either purchasing it or begging for it, and there is not a single tittle nor a single iota in this book which his hand did not write.' See Berschin and Zeller, 'Winithar in Sankt Gallen', p. I62, for the first, slightly different edition of these four passages.

" See Berschin and Zeller, 'Winithar in Sankt Gallen', p. I60: the fact that Winithar calls himself presbiter, and not, for example, decanus, could imply that the manuscript St Gallen 238 was produced around 760. 
Table I St Gallen, Stiftsbibliothek, 238: contents

\begin{tabular}{|c|c|}
\hline pp. 2-I63: & glossary \\
\hline pp. $163-78:$ & Jerome, Epistola 36 to Damasus + Prologue to Genesis \\
\hline pp. I78-8I: & $\begin{array}{l}\text { 'Dicta/proplema Winitharii' = question/answer introduction to the } \\
\text { Pentateuch }\end{array}$ \\
\hline pp. I8I-5: & $\begin{array}{l}\text { Isidore, Sententia I.8: De racione mundi (about Genesis) + anonymous } \\
\text { text on the creation of the angels }\end{array}$ \\
\hline pp. I86-28r: & $\begin{array}{l}\text { Pentateuch: question/answer résumé of the main contents and } \\
\text { problems }\end{array}$ \\
\hline pp. 282-4: & Jerome, Prologue to Joshua \\
\hline pp. 284-304: & $\begin{array}{l}\text { Joshua, Judges, Ruth: question/answer résumé of the main contents } \\
\text { and problems }\end{array}$ \\
\hline p. 305: & Winithar's (?) prologue to the Liber Generationis of Jesus \\
\hline pp. 306-I2: & Genealogies of Jesus + chronology (main source: Isidore, Chronicon) \\
\hline pp. 312-84: & Isidore, De natura rerum \\
\hline pp. 384-5: & 'Liber de ordinacione solis vel reliqua' = Georgica I.23I-44 \\
\hline pp. $385-92:$ & 'De gentibus' = Ps.-Methodius, Revelationes, third recension \\
\hline p. 392: & Apocalypse XI.3-I3 \\
\hline pp. 392-6: & 'De gentibus' $=$ extracts from Isidore, Etymologiae IX.2 \\
\hline pp. 396-4I4: & $\begin{array}{l}\text { Ps.-Seneca, De moribus (last part, from p. 406, drawn mostly from } \\
\text { Isidore, Synonyma) }\end{array}$ \\
\hline pp. 415-34: & Gennadius, De ecclesiasticis dogmatibus \\
\hline pp. 434-51: & 4 Books of Kings: résumé of the main contents and problems \\
\hline pp. 45I-75: & $\begin{array}{l}\text { Prologues to each of the major and minor prophets (from Jerome and } \\
\text { ps.-Jerome) }\end{array}$ \\
\hline pp. 475-93: & Eucherius, Instructiones, 2nd book almost complete \\
\hline p. 493: & Winithar's final subscription \\
\hline
\end{tabular}

explained through synonyms or brief sentences. ${ }^{12}$ This rich and somewhat artful glossary covers the first 163 pages, providing not only a compendium of lexicographic material of varied origins, but also a linguistic tool for the elucidation of the following texts. Although I have not attempted a systematic reconstruction of the possible sources of the various items, it is nevertheless apparent that some of them either explain difficult words appearing afterwards in the book or are drawn from those texts of the manuscript which are more didactic in nature. The word prolocus/

12 Independently Rosamond McKitterick had also started work on this manuscript from a different perspective, that of glossaries as a historical and cultural phenomenon, highlighting the 'energetic engagement with words' which took place at Saint-Gall in the second half of the eighth century. See her contribution, 'Glossaries and Other Innovations in Carolingian Book Production', in E. Kwakkel, R. McKitterick and R. Thomson, Turning Over a New Leaf: Change and Development in the Medieval Book, Studies in Medieval and Renaissance Book Culture (Leiden, 20I2), pp. 2I-78 and Plates I-2O, but the study here complements hers. For further information about Winithar as a scribe and his enterprise at Saint-Gall, see also R. McKitterick, 'Le pouvoir des mots', in J. Prouhon (ed.), Les écoles monastiques au haut moyen âge, Les cahiers colombaniens (Luxeuil, 20I4). 
prologus, for example, recurs at many points in the manuscript and is explained in the glossary on p. I23; the word proplema, which appears quite often in the final part of the Judges summary (e.g. at p. 299) and in Winithar's self-reference on p. I8I (Explicit proplema Winitharii presbiteri) receives a threefold explanation in the glossary (p. I22). Furthermore, terms such as episcopus, omosion, or tebeth are present both in the initial glossary and in the sections De mensibus and De graecis nominibus from the second book of Eucherius's Instructiones, which closes the manuscript. Characteristic of the glossary, moreover, are the sentences, resembling tituli, which almost always introduce the next alphabetical group of words. These tituli consist mostly of paraphrases of biblical accounts or quotations from geographical sources. ${ }^{13}$

Thus the work leading to the production of the initial glossary seems strictly related to the process of selective copying and summarizing which gave rise to the rest of the book. In other words, the initial glossary seems to assume the dual function of a propaedeutic, tailored vocabulary to the contents of the manuscript, and of a summary of specific information given there. If these assumptions are correct, placing such a rich glossary at the beginning of a mostly biblical compendium would reflect that propaedeutic function which such texts as Cassiodorus's Institutiones or Alcuin's Grammatica assign to the artes liberales in connection to the study of the Bible. ${ }^{14}$

The section of the volume up to p. $3 \mathrm{I} 2$, which in my opinion is the second section of this manuscript, is mostly dedicated to the first eight biblical books (from Genesis to Ruth) and to chronological issues, aiming to recapitulate the history of humankind from Adam to Jesus. After Jerome's Epistle 36 to Damasus concerning problems of translation with specific reference to the book of Genesis, the manuscript presents Jerome's prologue on Genesis and then a text, introduced and followed by two of Winithar's self-references: Incipit dicta Winitharii presbiteri de quinque libris Moysi added on the margin of p. 178, and Explicitproplema Winitharii presbiteri on p. 18I. As noted above, the word proplema received a threefold explanation in the initial glossary and means in its plural form 'those texts/speeches that pose questions' (qui quaestiones faciunt, p. I22). This text indeed, which Winithar claims as his own composition, is written in

${ }^{13}$ Very interesting, for example, is the titulus introducing the section 'Ka' on p. 87: 'Incipit de K et de A. Kalidus serpens cum suis sodalibus, qui se extulit olim contra domino, catenatus demersus est in abisum, qui accusabat fratres ante domino.' The last phrase in particular could be an allusion to the internal tensions between monks at Saint-Gall at the beginning of the $760 s$, to which Winithar explicitly refers in the Versus Winitharii: cf. Berschin and Zeller, 'Winithar in Sankt Gallen', p. I59.

${ }^{14}$ Cassiodori Senatoris Institutiones, ed. R.A.B. Mynors (Oxford, 1937); trans. J.M. Halporn with introduction by M. Vessey, Institutions of Divine and Secular Learning and On the Soul (Liverpool, 2004); Alcuin, Ars Grammatica, PL IOI, cols 754-902. 
a question and answer form and aims to explain some introductory points to the Pentateuch, such as: what is the meaning of the name Genesis? How could Moses write these books being illiterate? To what extent is Moses a prefiguration of Jesus? Introductory and recapitulatory material about Genesis also forms the core of Isidore's Sententia I.8 De racione mundi, which was copied afterwards up to p. 185. Following this there is a long section up to p. 304, in which the main contents of the Pentateuch and of Joshua, Judges and Ruth are summarized, once more in question and answer form. A peculiarity of this group of texts is worth noting: on p. 280 the compendium of Numbers comes to its end, while a red, uncial title introduces the question-and-answer summary on Joshua (Incipit de Iusue ministro Moyse), which is copied afterwards in quite a small and disorderly minuscule. On the following page the current quire ends, marked at the bottom of the leaf with the letter 'S', as does the Joshua summary abruptly. On p. 282 a second, artfully written title warns the reader to ignore the previous page because it is from this point that the same book on Joshua actually begins ('Pretermitte illum folium ad sinistram inceptum de Iusue, quia de isto loco incipit ipse liber'). The scribe now copies firstly Jerome's prologue on Joshua and after this the entire question-and-answer summary that is already present in its initial part on pp. 280-I. It seems indeed that, due to a lack of parchment, Winithar was forced to interrupt the writing of the Joshua summary on p. 280 , where the quire ' $S$ ' ends. Later, presumably when new leaves were available, he could again start copying the texts included in his editorial project with renewed energy. That parchment was a precious and rare material at this early stage of Saint-Gall's history is suggested by at least two allusions Winithar makes to his difficulty in procuring it. The first is in the final colophon of this manuscript, already quoted above, where he affirms somewhat proudly that he has personally gathered every single leaf of the book, buying it himself or begging for it. Secondly, in the second chapter of the Versus Winitharii, (St Gallen, Stiftsbibliothek, MS 70, pp. 250-8), he begs his confrères for parchment in order to write something useful for the community. ${ }^{\text {I5 }}$

With parchment no longer a problem, Winithar could indeed add both prefatory material (Jerome's prologue) and decorative elements, such as red-green-coloured uncial titles and decorated initials. ${ }^{16}$ Furthermore, he could write again with a steadier and larger minuscule, returning in this manner to the characteristic page layout of the manuscript, as occurs for instance on p. I86, where the first question-and-answer résumé

is The first edition of the Versus can now be found in Berschin and Zeller, 'Winithar in Sankt Gallen': see esp. p. I6o with n. 32 and p. I70.

I6 See <http://www.e-codices.unifr.ch/it/csg/0238/282>. 
of the Pentateuch begins. The summary of Judges, which ends with an accurate account of Samson's deeds, is followed by a short text on the book of Ruth. This biblical book ends with a genealogy down to King David; Winithar adds in his résumé a brief sentence ('de ista generacione ortus est Christus', p. 304) that serves as a bridge to the next group of texts. The following seven pages are indeed mostly dedicated to a comparison of the genealogies of Christ in Matthew's and in Luke's Gospels, as well as to chronological questions connected to them. These texts recapitulate briefly the succession of years that links the creation of the world to the birth of Christ, also describing the time after Christ as progressive movement towards the end of the world. Some aspects of these pages are worth stressing: firstly, Winithar seems to claim the authorship of the prologue to the Liber Generationis as his own ('Explicet prolocus, quem Winitharius presbiter ex sua scripsit memoria', p. 305). While the Liber Generationis (pp. 306-8) is probably a compendium of former exegesis, as Bonifatius Fischer supposed, the prolocus of p. 305 could indeed be ascribed to Winithar. ${ }^{17}$ Secondly, two brief genealogies of Cain and of Ishmael are copied on p. 308, after the Liber Generationis of Christ. Finally, the chronological part displaying the succession of years from Adam to Christ (pp. 308-I2) is mostly based on the Chronicon of Isidore and, through this, on the Chronicon of Eusebius-Jerome.

Isidore is also the most relevant reference for the next section, which I consider to be the third one in the manuscript (pp. 3I2-434). After having retraced human history from the Creation to the birth of Christ, Winithar aimed in this part of the book to describe on the one hand the astronomic and natural elements of reality, and on the other the characteristics of specific peoples and the ideal behaviour of humans. Every text was copied, not composed, by Winithar: in fact, it is always possible for the modern reader, even if the titles do not offer any information, to identify the sources of this section and to link these texts to the name of an author, be he real or fictitious. Moreover, the large majority of these texts are very didactic in nature, listing and explaining, as they do, the various names and characteristics of natural phenomena, of peoples, and of human virtues or vices. As in the initial glossary, names and definitions again play a key role here. Also Winithar's predilection for genealogies

${ }^{17}$ B. Fischer, Lateinische Bibelhandschriften im frühen Mittelalter (Freiburg, 1985), p. 180, cited in Berschin and Zeller, 'Winithar in Sankt Gallen', p. I54. In the future, a more detailed search for the sources underlying this prologue will establish whether the sentence 'quem Winitharius presbiter ex sua scripsit memoria', which was added later after explicet prolocus, means that Winithar is the author of this text or the one who selected passages on this topic that he already knew and had in mind. In a similar manner, a search for the sources of the various biblical résumés of this section (pp. 163-312) will show whether they can be considered as Winithar's original work. 
and chronologies is further confirmed in this part of the book, as we shall see. The first work he decided to copy was the whole text and the circular illustrations of Isidore's De natura rerum under the title Liber Rotarum ('Incipit liber rotarum sancti Hysidori', p. 3I2). ${ }^{18}$ Most of the illustrations or diagrams accompanying the text are indeed rotae, i.e. wheels or circles, which are used as a frame for words or short sentences that summarize specific information included in the Isidorian chapters. The text is followed by a short treatise about the division of the sky and the constellations, under the title Liber de ordinacione solis vel reliqua: this short extract reproduces the wording, but not the partition in verses, of thirteen lines (vv. 23I-44) from the first book of Vergil's Georgics. ${ }^{19}$ On p. 385 Winithar begins a twelve-page section about peoples, De gentibus, to which I shall return below. After this there is quite a long passage (pp. 396-434) of a moral and doctrinal nature, which begins with a work called De moribus attributed to Seneca. ${ }^{20}$ A red uncial title introduces the prologue to the work ('Incipit prolocus libri Senicae'), which is a short accessus to Seneca's alleged biography. The work itself consists of a collection of proverbs and advice regarding correct moral behaviour, which towards the end show a predominantly Christian inspiration (from p. 406). From this point, indeed, extracts from Isidore's Synonyma become the major source of the collection. ${ }^{2 \mathrm{I}}$ At the bottom of p. 4I4 Winithar marks the end of the De moribus with a curious explicit, written in the same minuscule as the text itself:

Gracias Deo finit liber Senicae; triplo qui scripsit cerbello isto sit sanus Deo: 'petite et tabitur (sic!) vobis, querite et invenietis, pulsate et aperietur' (Matthew VII.7)

I8 For a modern edition of Isidore's De natura rerum including St Gallen 238 as witness of the so-called recension longue, see J. Fontaine, Isidore de Séville. Traité de la nature (Bordeaux, I960; repr. Turnhout, 2002). For new perspectives on Winithar's work see V. von Büren, 'La transmission du De moribus du Ps. Sénèque, de Winithar de S. Gall à Sedulius Scottus', in P.F. Alberto and D. Panagua (eds), Ways of Approaching Knowledge in Late Antiquity and the Early Middle Ages. Schools and Scholarship (Nordhausen, 20I2), pp. 206-44. Von Büren suggests an Italian origin for Winithar on account of both the provenance of the manuscripts he uses as sources and the idiosyncratic palaeographical traits of his hand, which in her view show Italian influences.

19 P.F. Alberto points out that this addition drawn from Vergil's Georgics can also be found after Isidore's De natura rerum in the manuscript Paris, Bibliothèque Nationale de France, lat. 4860, produced in the first half of the ninth century at Reichenau, where it was copied preserving the original division into verses. See P.F. Alberto, 'King Sisebut's Carmen de luna in the Carolingian School', in Alberto and D. Panagua (eds), Ways of Approaching Knowledge in Late Antiquity and the Early Middle Ages, pp. 177-205, at p. I85, n. 3I.

20 A critical edition of this work is available in E. Wölfflin, Publilii Syri Sententiae (Leipzig, I869), pp. 136-48. Information about both the origin of the title De moribus and some witnesses thereof can now be found in V. von Büren, 'La transmission', pp. 206-I4.

${ }^{21}$ A detailed search for the sources of the De moribus as attested in St Gallen 238, a complicated task indeed, is still lacking. 
which could perhaps be translated as follows:

Thank God Seneca's book ends; may the man (Seneca? or perhaps Winithar himself?), who wrote it with this triple intention, be righteous in front of God: ask, and it shall be given you; seek, and you shall find; knock, and it shall be opened to you.

Neither the critical edition by Wölfflin nor the recent article by Veronika von Büren help us to understand whether this explicit recurs in other manuscripts of De moribus. I tend to think that it is an original composition by Winithar. Qui scripsit can refer to Seneca, who could have written the De moribus with the conviction of achieving something good, but it can also refer to the scribe himself, i.e. Winithar, who could have copied this work with the triple intention (this is how I translate cerbello) of asking, seeking and knocking on the hearts of his confrères, proposing to them a useful work for their moral improvement. If this interpretation is correct, the copying of the De moribus would have been undertaken in accordance with what Winithar promises to the monks at Saint-Gall in the second chapter of his Versus. ${ }^{22}$

On the next page of the codex Gennadius's De ecclesiasticis dogmatibus begins (pp. 415-34), a work of doctrinal nature that summarizes some of the principal aspects and practices of the Christian faith. The red uncial title on p. $4 \mathrm{I} 5$ introduces the work under the designation docma without revealing the author's name.

In the final part of the manuscript (pp. 434-93) the Bible acts once more as principal focus: in fact, the compiler resumes the work of summarizing the Holy Scripture from the point where he left off. After the Book of Ruth (completed on p. 304) he now presents a summary of the four Books of Kings, then a complete set of prologues to the four major and to the twelve minor prophets drawn from Jerome or Ps.Jerome. After that Winithar concludes his work as he opened it, that is, with a linguistic tool: the final leaves of St Gallen 238 (pp. 475-93) feature the second book of Eucherius's Instructiones, in which some of the biblical names of people, places, rivers, clothing, and so on receive an explanation.

To summarize, both the contents and the codicological observations about the quire ' $S$ ' suggest that Winithar had a specific, unitary project in mind when writing this manuscript. His editorial plan was indeed of a universal nature and aimed at the following: firstly, to reconstruct the history of the world up to the birth of Jesus on the basis of biblical

${ }^{22}$ V. von Büren, 'La transmission', and see n. I5 above. 
accounts and of chronological interpretations; secondly to describe the natural properties of the world, the characteristics of specific peoples and the ideal moral behaviour of every human being; thirdly, to supply a linguistic tool for understanding the Bible by means of the initial glossary and the final explanations by Eucherius.

\section{De gentibus: a reuse of Rome's potential?}

Let us now concentrate on the pages dedicated to the peoples (pp. 385-96) and see what role Rome and the Romans assume in such an ambitious and all-embracing framework. Winithar chose to copy two texts to deal with peoples and gave both of them the title De gentibus.

The first is unexpected and quite surprising since it is a hitherto unknown and unrecorded witness, the oldest one actually, of the Revelationes by pseudo-Methodius in its so-called third Latin recension. Up until now this recension was attested only in a manuscript from Reichenau, the Karlsruhe, Badische Landesbibliothek, Augiensis 254 (fols $204 \mathrm{r}-2 \mathrm{IIr}$ ), written either in northern Italy or in the region of present-day Switzerland at the turn of the eighth century. ${ }^{23}$

The Revelationes were originally written in Syriac, probably around the year 690, by a Christian author who lived under Arabic rule. The text exhibits the traits of an apocalyptic prophecy in the form of a sermon and from the beginning it was ascribed to the fourth-century bishop Methodius of Olympus. Around 700 the Syriac text was translated verbatim into Greek, and probably around 720 the first, almost faithful translation from Greek into Latin was already available; ${ }^{24}$ this is a clear sign of the interest the text immediately aroused in a very wide audience. After the first Latin translation a second and a third Latin recension soon followed. ${ }^{25}$ The modern editors of the first Latin recension stress that a copy of it must have reached both Saint-Gall and Reichenau quite soon,

23 Hereafter Aug. 254. The manuscript and its standard description by A. Holder are available online at $<$ http://digital.blb-karlsruhe.de/blbhs/Handschriften/content/pageview/53463 $>$. For a list of the witnesses of the Revelationes in its various recensions see M. Laureys and D. Verhelst, 'Pseudo-Methodius, Revelationes: Textgeschichte und kritische Edition. Ein Leuven-Groninger Forschungsprojekt', in W. Verbeke, D. Verhelst and A. Welkenhuysen (eds), The Use and Abuse of Eschatology in the Middle Ages (Leuven, I988), pp. II2-36.

24 For the edition of the Syriac text see Die syrische Apokalypse des Pseudo-Methodius, ed. G.J. Reinink, 2 vols, Corpus Scriptorum Christianorum Orientalium 540-I (Leuven, I993). For the Greek and the Latin text of the first recension see: Die Apokalypse des Pseudo-Methodius. Die ältesten griechischen und lateinischen Übersetzungen, ed. W.J. Aerts and G.A.A. Kortekaas, 2 vols, Corpus Scriptorum Christianorum Orientalium Subsidia 97-8 (Leuven, 1998), with a rich introduction and commentary.

25 The genesis, the contents and the reasons for the enormous success of the first and second Latin translations are analysed in C. Gantner, 'Hoffnung in der Apokalypse? Die Ismaeliten in den älteren lateinischen Fassungen der Revelationes des Pseudo-Methodius', in V. Wieser, C. Zolles, 
where the oldest witnesses of the second and of the third recension respectively were produced. ${ }^{26}$ Yet the present contribution demonstrates that the oldest-known witness of the third recension also originated in Saint-Gall. Having nothing to do with the Greek text, the second and third recension abridged and rearranged the first Latin version, creating quite different narratives, as we shall see.

The reason for the success of the Revelationes lies most likely in its contents and in its message. Therefore, I shall first summarize the text of the first recension and then compare it with the third recension, adopted here by Winithar.

The first Latin recension is organized in fourteen chapters. The first nine form the historical part of the work, where pseudo-Methodius describes the descent from Adam to Noah, the Flood and the descendants of Noah, paying particular attention both to Jonitus, a son of Noah, who is not mentioned in the Bible, and to his descent. In Chapter 5 a descendant of Jonitus invades the desert of Yathrib (lying in modern-day Saudi Arabia) from the east and causes the dispersion of the sons of Ishmael, who live there. In accordance with Genesis, the Ishmaelites are only briefly introduced here as the descendants of Ishmael, the son of Abraham, and of the Egyptian servant Hagar. In turn the Ishmaelites invade the Promised Land and the Mediterranean region, until Gideon, a judge of Israel, finally beats them and drives them back to the desert of Yathrib. At this point pseudo-Methodius warns the reader that in the future they will leave this region once more and invade the western world, but they will be defeated by God and by the Romans. These Romans are, at least in the Syriac, Greek and first Latin version, the Romans of Byzantium. The historical narration continues with the description of the realm of Babylon. Chapters 8 and 9 aim to show that the realms of the Ethiopians, Macedonians, Greeks and Romans are strictly tied to each other, and that the Christian Roman empire of Byzantium is their direct continuation. In this passage pseudo-Methodius begins by recalling first the deeds of a Christianized Alexander the Great, the king of the Greeks, whose most glorious victory, with God's help, was the imprisonment of twenty-two unclean nations (including Gog and Magog) behind bronze gates in the furthest regions of the north. Following this the author outlines what might be described as a line of descent from Alexander, according to which his Ethiopian mother married his general Byzas and had with him a daughter called Byzancia. Byzancia married the Roman

C. Feik, M. Zolles and L. Schlöndorff (eds), Abendländische Apokalyptik. Kompendium zur Genealogie der Endzeit (Berlin, 20I3), pp. 52I-48, to which I refer also for further bibliography on the Revelationes.

${ }^{26}$ Die Apokalypse des Pseudo-Methodius, ed. Aerts and Kortekaas, I, p. 32. 
king Romolus and had with him three children, who then reigned respectively over Rome, Byzantium and Alexandria, all territories at the author's time under Byzantine rule. This Christian Byzantine empire, legacy of Alexander the Great, shall prevail over all other nations, according to the conclusion of Chapter 9, because the cross upon which Jesus hung is its invincible weapon.

With Chapter Io the actual prophetic part of the Revelationes begins: the author foresees a second invasion of the Ishmaelites, allowed by God as punishment for the sins of the Christians. Their brutalities will be innumerable and bring many Christians to desperation and apostasy. There will be a time of great poverty and pestilence until the king of the Romans/Byzantines suddenly appears and defeats the invaders, driving them back from whence they came. But the peace will soon be broken by the unexpected appearance of the peoples of the north, who will overcome the bronze gates. Only one of God's commanders will manage to wipe them out. The final chapter foresees the advent of the son of perdition: facing this event the king of the Romans will ascend Golgotha, place his crown on the cross and die, entrusting the salvation of the Christians directly to God. The son of perdition will dwell in Jerusalem, where he will be accused and rebuked by two servants of God, Enoch and Elijah, who are therefore destined to die soon. In the final scene pseudoMethodius foresees the advent of Christ, the defeat of the son of perdition and Judgement Day.

Let us now see how this narrative was abridged and rearranged in the so-called third recension so that we can try to understand why Winithar decided to adopt this very text in order to describe peoples. It is important to stress that Winithar certainly knew the first recension: in fact, one of the manuscripts in which his hand has been identified, namely St Gallen, Stiftsbibliothek, MS 225, contains it. He also probably knew the second recension (see n. 25 above): between the available versions of the Revelationes he consciously preferred the text of the third recension.

The third recension omits many chapters as well as the division between the historical and the prophetic section: ${ }^{27}$ what remains is mainly the account of the future clash, in novissimis diebus (in the last days), between the Ishmaelites and the king of the Romans. Adding a short genealogy from Shem to Ishmael, ${ }^{28}$ the third recension explicitly affirms

27 A critical edition of the third recension is still lacking. The following considerations rest on my transcriptions of the two known witnesses, which I intend to publish in a future article.

28 This addition begins with Shem in the Reichenau MS and with Ragau in our MS. The genealogy follows Genesis XI and draws on Isidore's Chronicon (ed. J.C. Martin, CCSL II2 (Leuven, 2003), pp. 20-30) with short insertions from his Etymologiae IX.2.6 and 57 (ed. W.M. Lindsay, 2 vols (Oxford, I9II), also available online at <http://penelope.uchicago.edu/Thayer/ E/Roman/Texts/Isidore/home.html>). 
that the Ishmaelites are now called (dicuntur) Saracens. Moreover, the king of the Romans rises without any possible doubt from Rome and not from Byzantium ('surgit rex Romanorum de Roma', St Gallen 238, p. 386; 'surgere habet rex Romanorum de Roma' Aug. 254, fol. 205v). The third recension preserves the account of Alexander's amazing fight against Gog and Magog and their final enclosure behind bronze gates in the north, as well as the strange lineage which demonstrates the ancestral role of the Ethiopian people. The realm of the Romans, which shall defend the Christians and defeat the Ishmaelites/Saracens, subjugating them under a terrible yoke, is the realm of the Romans of Rome, which descends from the Ethiopians and will last until Judgement Day. The importance of Ethiopia in this genealogy can be explained with the exegesis of Psalm LXVII.32 ('Ethiopia shall soon stretch out her hands to God') quoted in the Revelationes and interpreted in the sense that Ethiopia, or better its descendants the Romans, will be the last to reign on earth and will in the end, facing the Antichrist, entrust the salvation of humankind directly to God. The last part of the text mentions only in passing the invasion of Gog and Magog, rather concentrating on the advent of the son of perdition, who bears here also the name of Antichristus. He will be rebuked, just as in the first recension, by two servants of God, Enoch and Elijah, who will therefore die. At this point Winithar shows once more his knowledge of the Bible and the great importance the Scripture holds in his universal vision, inserting the passage of John's Apocalypse (XI.3I3), where two prophets bear testimony to God and are therefore killed by the Beast. Winithar evidently interprets this biblical quotation as a reference to the passage of the Revelationes, and feels free to interrupt the narrative by adding the scriptural text. Incidentally, the fact that the Reichenau manuscript does not have this insertion encourages the notion that it was Winithar's initiative to add it here. After this, Winithar again takes up the copying of the final part of the third recension with the description of the terrible times under the Antichrist, his final defeat after the coming of Jesus, and Judgement Day.

This is the end of the first text Winithar uses to focus on peoples. The title he chooses is De gentibus, whereas the other testimony of the third recension, the Reichenau manuscript, maintains almost the same title as in the first recension, namely 'Saint Methodius' words (dicta) about the realms of the kings as well as his certain demonstration about the last days'. Thus, the apocalyptic nature of the source, although still present in the text, is not reflected in the sobriety of Winithar's title. Peoples constitute the centre of his interest, but only two peoples receive a genealogical description in the third recension and come ultimately to the fore: the bad Saracens, who attack the west, and the good Christian Romans, who will defeat them. In a time such as the eighth century, 
when western Europe was increasingly subjected to Arabic pillaging and expansion, it is easy to understand why Winithar chose this text. Not only does it offer a description of the Saracens, but it regards them as villains in the Christian history of salvation. More surprising, however, is the importance Winithar bestows on the Romans, and not only through the third recension, but also through the second text bearing the title $D e$ gentibus, which he copies immediately afterwards (pp. 392-6) and which consists of extracts from the ninth book of Isidore's Etymologies. The first people named are the Romans, who are by no means the first in Isidore's text. ${ }^{29}$ After them, Winithar chose to copy Isidore's description of the Goths, Lombards and the Germanic peoples in general, the Suevi, Burgundians, Saxons, Franks, Britons and Scotti, Gauls, and finally the Vascones (Basques). It is easy to see that Winithar is only concerned with mentioning and describing, by means of this second text, the peoples of western Europe.

To conclude, Winithar's intentions in copying firstly the third recension, a text probably written around the middle of the eighth century, and then this particular abridgement of the Etymologies, were to focus on the west and to present a clash between the enemies coming from the east, the Saracens, and the western peoples of Europe headed by a king of the Romans rising from Rome. These are the only gentes to whom Winithar is willing to give special attention in the all-embracing historic framework of his book, starting with Adam and reaching until the end of time. Thus, if it is clear that the defence of the western peoples shall come from Rome, who are these Romans, who, after Rome's fall, hold such an eminent position? And who is their king?

It is not easy to offer a reliable answer to these questions: while the Saracens were indeed a clearly identifiable people both for the author of the third recension and for Winithar, as well as such a tangible threat for eighth-century Europe that they could be presented as the ultimate enemy, a straightforward identification of the Romans as a still-existing people was no longer obvious at that time. But precisely this indeterminacy allowed a variety of interpretations, all resting on the many conceivable ways to be Roman, as Walter Pohl has indicated in his contribution to this volume. Therefore it could be interesting to reflect about which associations Winithar wanted to arouse in his audience by proposing a text such as the third recension, in which the Romans and their king are to the fore.

29 See the quotation and the interpretation of this passage offered by Walter Pohl's contribution in the present volume. 
The Romans of the Revelationes are undoubtedly Christians, ruled by a Christian king; in the third recension they have in addition their reference point in Rome. Supposing that the monks at Saint-Gall were the intended audience of Winithar's work, as some of the abovementioned evidence indicates, it is perhaps possible that Winithar wanted to induce them to identify the victorious king of the Romans with a member of the Carolingian house - be he Charles Martell, who stopped the Muslim attacks in Aquitaine, or Pippin III, who fought against the Saracens at Narbonne and, more importantly, received from a Roman pope the title of patricius Romanorum and was anointed as (Christian) king of the Franks. If we consider that Winithar probably came to Saint-Gall following the abbot Johannes, who was a supporter of new Frankish rule in Alemannia and had replaced the deposed abbot Otmar, this suggested association between the Carolingians and the Romans (the defenders of the Christian faith and the leaders of western European peoples, as the Isidorian abridgement reminds the reader), was probably not a coincidence.

Institut für Mittelalterforschung, Österreichische Akademie der Wissenschaften 